\title{
Effects of Subarachnoid Clonidine Spinal Anaesthesia with Hyperbaric Bupivacain
}

\author{
M. Roesli Thaib
}

\begin{abstract}
Abstrak
Penelitian ini dirancang untuk menentukan pengaruh penambahan klonidin ke dalain larutan bupivakain hiperbarik 0,5\% pada analgesia spinal untuk bedah abdomen bawah, perineum dan tungkai bawah. Observasi prospektif dilakukan pada 40 pasien ASA I - II yang berusia antara 20 - 70 tahun. Pasien dibagi dalam dua kelompok secara acak, masing-masing terdiri dari 20 orang. Pasien kelompok I mendapat $3 \mathrm{ml}$ bupivakain hiperbarik 0,5\% + $1 \mathrm{mlNaCl}$; sedangkan pasien kelompok II mendapat $3 \mathrm{ml}$ bupivakain hiperbarik $0,5 \%+1 \mathrm{ml}$ klonidin $(0,15 \mathrm{mg})$. Yang dibandingkan pada kedua kelompok adalah waktu untuk mencapai blokade motorik total, ciriciri blokade motorik dengan nilai Bromage 0,1,2,3; ciri-ciri blokade sensorik berupa waktu yang diperlukan untuk mencapai blok sensorik maksimum dan waktu untuk mencapai regresi blokade sensorik sampai segmen L2. Rata-rata ketinggian analgesia, waktu untuk mencapai blokade motorik dan level maksimum blokade sensorik yang diperlihatkan oleh kedua kelompok berbeda tidak bermakna secara statistik. Lama blokade motorik Bromage 1,2 dan 3 pada kedua kelompok berbeda bermakna. Lama blokade motorik Bromage 1,2 dan 3 masing-masing berlangsung, $(288 \pm 60),(215 \pm 60)$ dan $(180 \pm 50)$ menit pada kelompok II. Waktu untuk mencapai regresi blokade sensorik kelompok II adalah $(268 \pm 60$ ) menit yang juga berbeda bermakna dari kelompok I. Perubahan sistem kardiovaskular, berupa tekanan darah sistolik, tekanan darah diastolik dan frekuensi nadi pada kedua kelompok tak berbeda bermakna. Efek samping yang tercatat selama penelitian adalah mulut kering dan mengantuk.
\end{abstract}

\begin{abstract}
This study was designed to determine the effects of clonidine addition to hyperbaric bupivacain $0.5 \%$ spinal analgesia for lower abdominal, perineal and lower limb surgery. A prospective observation was conducted on 40 ASA class I or II patients aged 20 - 70 years. The subjects were randomly allocated into two groups; each group consisted of 20 patients. Group I patients recieved $3 \mathrm{ml}$ of hyperbaric bupivacain $0.5 \%$ plus $1 \mathrm{ml}$ normal saline; group II patients recieved $3 \mathrm{ml}$ of hyperbaric bupivacain $0.5 \%$ plus $1 \mathrm{ml}$ clonidine $(0.15 \mathrm{mg})$. Both group were compared concerning; time to onset of total motor block; characteristics of motor block using Bromage scale 0,1,2, and 3; characteristics of sensory block about the time to achieve maximum level of sensory block and the time for regression of sensory block to segment L2. Average analgesia level, the time to achieve motor blockade and sensory blockade in both groups showed no statistically significant difference. The duration of motor blockade Bromage scale 1,2 and 3 in both groups showed statiscally significant difference. Duration of motor blockade Bromage scale 1,2 and 3 was (288 \pm 60$),(215 \pm 60)$ and (180 \pm 50$)$ min. in group II. Time for regression of sensory blockade of group II was (268 \pm 70$)$ min, that was also different significantly than group I. The changes of cardiovascular system concerning, systolic blood pressure, diastolic blood pressure and heart rate were no statistically significant difference in both groups. Side effects, sedation and dry mouth were found in several patients of group II.
\end{abstract}

Keywords : Spinal anaesthesia, local, Anaesthetic, local (bupivacain), Adrenoreceptor agonist (clonidine).

Since 1966, hyperbaric bupivacain $0.5 \%$ has been used for spinal anesthesia due to adequate analgesia effect and its long duration of action. ${ }^{1,2,3}$ Certain surgical procedures need a prolonged time. It was reported by several reseachers that the addition of clonidine to bupivacain solution achieved longer analgesic effect, measured by analgesia level, onset time, duration of action, time of achievement of maximal sensory block, hemodynamic effects and side effects that might happen during spinal analgesia. Surgical procedures included low abdominal surgery, perineal surgery and lower limb surgery. 
Clonidine is an alpha adrenoreceptor agonist which selectively stimulates pre and post-synaptic areas of the central and peripheral nervous system. ${ }^{4,5,6}$ Activation of the central alpha adrenoreceptor is the strongest influence of this drug with associated lowering of sympathetic tone, increase of parasympathetic tone, sedation and effects analgesial. ${ }^{6}$

In binding experiments, it has been shown that the spinal cord contains beta, alpha 1 and alpha 2-adrenoreceptors. ${ }^{7,8,9}$ The distribution of alpha 2 -adrenoreceptors is found mainly in the substantia gelatinosa of the dorsal horn, with lower densities over the intermediolateral cell column, and around central canal. ${ }^{9,10}$ The localization of the binding to the main pain afferent terminal region of the spinal cord supports the conclusion that alpha 2-adrenoreceptors have a role in pain modulation. Inotophoretically administered clonidine into the spinal cord produces a selective inhibition of nociceptor-specific nervous activity. Alpha 1-adrenoreceptors and beta-agonists were found to be inactive. ${ }^{11}$

Reports have recently appeared suggest that intrathecal or epidural alpha-adrenoreceptor agonists may also be useful analgesic agents for the relief of pain. Thus, intrathecal noradrenergic agonists have antinociceptive effects. ${ }^{12}$ Spinally administrered clonidine inhibits spinal substance $\mathrm{P}$ release and nociceptive neuron produced by noxious stimuli and produces analgesia. ${ }^{13}$ Recent reports have shown clonidine to be a good adjunct to epidural routes in humans. The effect of clonidine on antinociception may be prolonged. Furthermore, animal work and human studies have not demonstrated neurotoxic or respiratory depressant effects following intrathecal administration. Clonidine, unlike intrathecally administered opiates, does not produce respiratory depression, nausea and vomiting, or pruritus.

This study was undertaken to evaluate the efficacy of clonidine in prolonging hyperbaric bupivacain $0.5 \%$ spinal analgesia.

\section{MATERIALS AND METHODS}

Forty men and women patients (ASA I - II) ${ }^{\star}$ scheduled for perineal surgery, lower limb surgery or low abdominal surgery, were included in the study after individual informed consent were obtained. The age of patients ranged from 20 to 70 years. The criteria of exclusion of the patients was, the presence of absolute or relative contraindications of spinal anesthesia. The operations were carried out in central operating theatre of Dr. Cipto Mangunkusumo Hospital, Jakarta.

The patients were allocated randomly into two groups :

1. Group I, consisted twenty patients; received $3 \mathrm{ml}$ hyperbaric bupivacain $0.5 \%$ plus $1 \mathrm{ml}$ of $0.9 \%$ sodium chloride.

2. Group II, consisted twenty patients; received $3 \mathrm{ml}$ hyperbaric bupivacain $0.5 \%$ plus $1 \mathrm{ml}$ of clonidine (0.15 mg).

Patients which were uncooperative or in need of additional narcotic analgesics or anesthetics and those whose operations were accompanied with severe complication such as, bleeding more than $30 \%$ of blood volume were excluded from this study.

Neither group were given premedications. Spinal anesthesia were performed in lateral decubitus position, with the operative side uppermost. Under aseptic condition, lumbal puncture was carried out with a 25 gauge needle at the L2-3 or L3-4 interspace using a midline approach. All injections were made at rate of about $1 \mathrm{ml}$ in 4-5 sec and all solutions injected were at room temperature. Immediately before induction of spinal analgesia, an 118 gauge cannula was inserted into an arm vein and $10 \mathrm{ml} / \mathrm{kg}$ BW of lactated Ringer's solution was infused in $15 \mathrm{~min}$. This was repeated after injection of spinal analgesic, infusion was maintained at 50 drops $/ \mathrm{min}$.

The time of completion of injection of the local analgetic solution into subarachnoid space was used as the starting point for measurement of all time intervals. The dermatome levels of sensory blockade were evaluated by puncture with needle and pinching bilaterally in a midclavicular line and on the legs with forceps at minute $2,5,10,15,20,25,30$ after injection. Sensory blockade was considered complete when the patients did not respond to this puncture or forceps. When levels of analgesia were not equal bilaterally, the higher level was used for statistical purposes.

Motor blockade was assessed at the same time as sensory levels using criteria described by Bromage ${ }^{14}$, as follows :

0 : No impairment of movement of legs and feet

1 : Barely able to flex knees, no impairment of movement of feet

2: Unable to flex knees, barely able to move feet

3: Unable to move feet or knees

Thereafter, analgesia, and motor block were assessed every $30 \mathrm{~min}$ until analgesia had regressed to

\footnotetext{
* ASA I : Normal and healthy pasients

ASA II : Patients with mild systemic disease
} 
the point that the cutaneous response to puncture and clamping in the operative site was identical to that on the forearm of for a maximum of 5 hours after injection.

Blood pressure and heart rate were measured 2 min. before spinal analgesia and at 2,5 min. intervals after injection for a period of $10 \mathrm{~min}$. and then at $5 \mathrm{~min}$. intervals for a period of $60 \mathrm{~min}$. during analgesia and $15 \mathrm{~min}$. postoperatively; using automatic electric sphygmomanometer (Dinamap, Criticon). The ECG was monitored continously during induction of analgesia and during surgery. When mean arterial pressure (MAP) decreased by more than $20 \%$ of preinduction values, the infusions were increased and $5-10 \mathrm{mg}$ ephedrine was injected intravenously, if needed.

All side effets, such as 'dry mouth', sedation, respiratory depression or urinary retention, etc that might happen during and after spinal analgesia were recorded. Values were expressed as Mean \pm Standard Error Mean (SEM). Statistical analysis used were Student's t test; $\mathrm{p}<0.05$ was considered statistically significant.

No statistically significant differences existed between the two groups regarding sex, age height and body weight $(\mathrm{P}>0.05)$.

Data of systolic blood pressure, diastolic blood pressure, mean arterial pressure and heart rate before spinal analgesia in both groups (Table 2) also showed no statistically significant differences.

Table 1. Characteristics of the Patients Studied

\begin{tabular}{lccc}
\hline Varia ble & $\begin{array}{c}\text { Group I }(\mathrm{n}=20) \\
\text { (Bupivacain }+ \\
\mathrm{NaCl})\end{array}$ & $\begin{array}{c}\text { Group II }(\mathrm{n}=20) \\
\text { (Bupivacain }+ \\
\text { Clonidine) }\end{array}$ & $\mathrm{P}$ \\
\hline Sex : Female & 2 & 3 & $>0.05$ \\
$\quad$ Male & 18 & 17 & $>0.05$ \\
Age (yr) & $48.6 \pm 4.43$ & $43.3 \pm 4.73$ & $>0.05$ \\
Weight (cm) & $161.6 \pm 5.28$ & $163.3 \pm 4.21$ & $>0.05$ \\
Weight $(\mathrm{kg})$ & $55.5 \pm 4.85$ & $57.5 \pm 4.27$ & $>0.05$ \\
\hline
\end{tabular}

Table 2. Systolic Blood Pressure, Diastolic Blood Pressure, MAP Heart Ratee before spinal analgesia

\begin{tabular}{|c|c|c|c|}
\hline Variable & $\begin{array}{c}\text { Group I }(n=20) \\
\text { (Bupivacain }+ \\
\mathrm{NaCl})\end{array}$ & $\begin{array}{c}\text { Group II }(\mathrm{n}=20) \\
\text { (Bupivacain }+ \\
\text { Clonidine) }\end{array}$ & $\mathrm{P}$ \\
\hline $\begin{array}{l}\text { Systolic Blood Pressure } \\
\text { mmHg }\end{array}$ & $134 \pm 15.31$ & $130.55 \pm 9.46$ & $>0.05$ \\
\hline $\begin{array}{l}\text { Diastolic Blood Pressure } \\
\mathrm{mmHg}\end{array}$ & $81.50 \pm 5.87$ & $80 \pm 7.95$ & $>0.05$ \\
\hline $\begin{array}{l}\text { Mean Arterial Pressure } \\
\text { mmHg }\end{array}$ & $97.07 \pm 7.54$ & $94.67 \pm 9.27$ & $>0.05$ \\
\hline Heart Rate $\quad x / m i n$ & $85.20 \pm 5.41$ & $87.1 \pm 5.74$ & $>0.05$ \\
\hline
\end{tabular}

\section{RESULTS}

The time of onset of motor blockage Bromage 1, Bromage 2, Bromage 3 did not differ significantly between both groups (Table 3). Significant differences in duration of motor blockage Bromage 1, Bromage 2 and Bromage 3 were found between group I and group II (Table 4). The duration of motor blockage Bromage 1, Bromage 2, Bromage 3 increased with administration of clonidine $(p<0.05)$.

Table 3. Time to onset Molor Blockage (minute)

\begin{tabular}{lcccc}
\hline Bromage I & Bromage 2 & Bromage 3 & P & \\
\hline $\begin{array}{l}\text { Group I } \\
\text { (bup. + NaCl) }\end{array}$ & $3.4 \pm 1.2$ & $5.2 \pm 2.0$ & $5.6 \pm 1.4$ & $>0.05$ \\
$\begin{array}{l}\text { Group II } \\
\text { (bup. + Clon) }\end{array}$ & $3.6 \pm 1.2$ & $6.0 \pm 2.0$ & $6.7 \pm 3.3$ & $>0.05$ \\
\hline
\end{tabular}

Table 4. Characteristics of Spinal Motor Blokage

\begin{tabular}{|c|c|c|c|}
\hline & Group I & Group II & $\mathrm{P}$ \\
\hline 1. Number of Patients & 20 & 20 & \\
\hline $\begin{array}{l}\text { 2. Time to onset of total } \\
\text { motor blockade (Brg. } 3 \text { ) }\end{array}$ & $(5.6 \pm 1.4) \mathrm{min}$ & $(6.7 \pm 3.3) \mathrm{min}$ & $>0.05$ \\
\hline $\begin{array}{l}\text { 3. Duration of motor } \\
\text { blockade, Brg. } 3\end{array}$ & $(105 \pm 25) \mathrm{min}$ & $(180 \pm 50) \min$ & $<0.05$ \\
\hline $\begin{array}{l}\text { 4. Duration of motor } \\
\text { blockade, Brg. } 2\end{array}$ & $(120 \pm 20) \min$ & $(215 \pm 60) \mathrm{min}$ & $<0.05$ \\
\hline $\begin{array}{l}\text { 5. Duration of motor } \\
\text { blockade, Brg. } 1\end{array}$ & $(140 \pm 25) \mathrm{min}$ & $(288 \pm 60) \mathrm{min}$ & $<0.05$ \\
\hline
\end{tabular}

Mean maximum levels of analgesia were similar in both groups (Table 5). The rate of spreading were also similar.

The time required to achieve maximum level of sensory blockage in both groups were not significantly different (Table 6). The duration of sensory blockage was significantly prolonged in group II, patients reciecving spinal clonidine $(268 \pm 70) \mathrm{min}$. Compared with group I, the mean time for regression of the level of sensory analgesia to L2 was significantly longer in group II ( $\mathrm{p}<0.05)$.

Systolic and, diastolic blood pressures were mildly decreased in al group after the $2.5 ; 5 ; 7.5 ; 10 ; 15 ; 20 ; 30$ min (Table 7 Table 8). Differences between the decreases in mean arterial pressures were not significant. Maximum decrease in blood pressure was not significantly more pronounced in the patients receiving spinal bupivacain plus clonidine. In both groups 
there were small but in significant changes in heart rate (Table 9).

A patient from group I showed side effects of shivering and postspinal headache; in group II 'dry mouth' were found in six patients; mild sedation in fifteen patients and shivering in five patients. Shivering shown by both group was not significantly different.

Table 5. Mean Maximum Level of Analgesia

\begin{tabular}{llll}
\hline $\begin{array}{l}\text { Time, after injection of } \\
\text { spinal anesthesia }\end{array}$ & Group I & Group II & P \\
\hline After 2 minutes & Th. $(11 \pm 1)$ & Th. $(10 \pm 1)$ & $>0.05$ \\
After 5 minutes & Th. $(9 \pm 1)$ & Th. $(8 \pm 1)$ & $>0.05$ \\
After 10 minutes & Th. $(7 \pm 1)$ & Th. $(6 \pm 1)$ & $>0.05$ \\
After 15 minutes & Th. $(7 \pm 1)$ & Th. $(7 \pm 1)$ & $>0.05$ \\
After 20 minutes & Th. $6 \pm 1)$ & Th. $(5 \pm 1)$ & $>0.05$ \\
After 25 minutes & Th. $(6 \pm 1)$ & Th. $(5 \pm 1)$ & $>0.05$ \\
After 30 minutes & Th.( $6 \pm 1)$ & Th. $(5 \pm 1)$ & $>0.05$ \\
\hline
\end{tabular}

Table 6. Characteristics of Sensory Blockage

\begin{tabular}{lccc}
\hline & Group I & Group II & P \\
\hline $\begin{array}{l}\text { Time to achieve maximum } \\
\text { level of sensory blockade }\end{array}$ & $(15 \pm 10) \mathrm{min}$ & $(16 \pm 7) \mathrm{min}$ & $>0.05$ \\
$\begin{array}{l}\text { Time for regression of } \\
\text { sensory blockade to L2 }\end{array}$ & $(158 \pm 20) \mathrm{min}$ & $(268 \pm 70) \mathrm{min}$ & $<0.05$ \\
\hline
\end{tabular}

Table 7. Changes of Sistolic Blood Pressures before and after Spina] Anaesthesia

\begin{tabular}{lllc}
\hline & Group I (mmHg) & Group II (mmHg) & $P$ \\
\hline $\begin{array}{l}\text { Before spinal } \\
\text { anesthesia }\end{array}$ & $134.00 \pm 15.31$ & $130.55 \pm 9.46$ & $>0.05$ \\
After 2.5 minutes & $129.75 \pm 14.99$ & $126.50 \pm 10.52$ & $>0.05$ \\
After 5 minutes & $127.70 \pm 14.60$ & $124.80 \pm 10.88$ & $>0.05$ \\
After 7.5 minutes & $125.90 \pm 16.60$ & $121.75 \pm 12.14$ & $>0.05$ \\
After 10 minutes & $123.85 \pm 15.21$ & $116.12 \pm 12.28$ & $>0.05$ \\
After 15 minutes & $119.80 \pm 16.70$ & $116.60 \pm 10.32$ & $>0.05$ \\
After 20 minutes & $117.65 \pm 14.38$ & $114.00 \pm 7.88$ & $>0.05$ \\
After 25 minutes & $115.75 \pm 7.12$ & $112.00 \pm 7.68$ & $>0.05$ \\
After 30 minutes & $114.75 \pm 7.12$ & $115.50 \pm 7.60$ & $>0.05$ \\
After 35 minutes & $116.00 \pm 6.81$ & $114.50 \pm 7.60$ & $>0.05$ \\
After 40 minutes & $116.50 \pm 6.70$ & $114.50 \pm 7.60$ & $>0.05$ \\
After 45 minutes & $117.50 \pm 7.16$ & $117.50 \pm 7.60$ & $>0.05$ \\
After 50 minutes & $117.58 \pm 6.80$ & $115.58 \pm 6.60$ & $>0.05$ \\
After 55 minutes & $116.50 \pm 7.30$ & $112.50 \pm 7.68$ & $>0.05$ \\
After 60 minutes & $114.40 \pm 7.40$ & $110.50 \pm 7.60$ & $>0.05$ \\
\hline
\end{tabular}

Table 8. Changes of Diastolic Blood Pressures Before and after Spinal Anaesthesia

\begin{tabular}{lllc}
\hline & Group I (mmHg) & Group II (mmHg) & $P$ \\
\hline Before spinal & & & \\
$\quad$ anesthesia & $87.65 \pm 7.06$ & $82.00 \pm 17.15$ & $>0.05$ \\
After 2.5 minutes & $79.65 \pm 7.58$ & $76.50 \pm 7.63$ & $>0.05$ \\
After 5 minutes & $76.80 \pm 7.43$ & $76.65 \pm 8.04$ & $>0.05$ \\
After 7.5 minutes & $74.90 \pm 7.58$ & $75.70 \pm 10.31$ & $>0.05$ \\
After 10 minutes & $75.10 \pm 7.91$ & $71.50 \pm 7.41$ & $>0.05$ \\
After 15 minutes & $75.85 \pm 8.75$ & $71.75 \pm 7.28$ & $>0.05$ \\
After 20 minutes & $74.20 \pm 7.82$ & $71.45 \pm 6.80$ & $>0.05$ \\
After 25 minutes & $73.30 \pm 8.95$ & $73.05 \pm 7.86$ & $>0.05$ \\
After 30 minutes & $72.95 \pm 6.98$ & $72.65 \pm 6.95$ & $>0.05$ \\
After 35 minutes & $74.15 \pm 6.65$ & $71.70 \pm 7.31$ & $>0.05$ \\
After 40 minutes & $74.05 \pm 6.65$ & $71.95 \pm 6.36$ & $>0.05$ \\
After 45 minutes & $74.75 \pm 5.41$ & $71.45 \pm 6.43$ & $>0.05$ \\
After 50 minutes & $74.10 \pm 6.12$ & $73.70 \pm 8.85$ & $>0.05$ \\
After 55 minutes & $73.20 \pm 6.21$ & $72.00 \pm 6.79$ & $>0.05$ \\
After 60 minutes & $74.55 \pm 5.43$ & $72.50 \pm 7.16$ & $>0.05$ \\
\hline
\end{tabular}

Table 9. Changes of Heart Rate before and after Spinal Anesthesia

\begin{tabular}{lllc}
\hline & Group I (mmHg) & Group II (mmHg) & P \\
\hline Before spinal & & & \\
$\quad$ anesthesia & $87.85 \pm 7.47$ & $90.55 \pm 8.15$ & $>0.05$ \\
After 2.5 minutes & $85.20 \pm 10.39$ & $86.25 \pm 7.64$ & $>0.05$ \\
After 5 minutes & $82.40 \pm 8.66$ & $85.60 \pm 8.36$ & $>0.05$ \\
After 7.5 minutes & $80.85 \pm 7.50$ & $81.60 \pm 6.62$ & $>0.05$ \\
After 10 minutes & $80.70 \pm 6.80$ & $81.70 \pm 7.60$ & $>0.05$ \\
After 15 minutes & $78.97 \pm 5.96$ & $79.00 \pm 7.78$ & $>0.05$ \\
After 20 minutes & $76.40 \pm 6.58$ & $75.00 \pm 7.38$ & $>0.05$ \\
After 25 minutes & $77.35 \pm 5.96$ & $74.80 \pm 6.26$ & $>0.05$ \\
After 30 minutes & $76.34 \pm 4.95$ & $77.95 \pm 8.45$ & $>0.05$ \\
After 35 minutes & $75.40 \pm 6.20$ & $76.94 \pm 8.44$ & $>0.05$ \\
After 40 minutes & $76.45 \pm 10.00$ & $77.10 \pm 9.43$ & $>0.05$ \\
After 45 minutes & $76.45 \pm 8.98$ & $77.35 \pm 10.79$ & $>0.05$ \\
After 50 minutes & $77.15 \pm 10.02$ & $78.25 \pm 11.42$ & $>0.05$ \\
After 55 minutes & $77.25 \pm 6.88$ & $80.15 \pm 10.56$ & $>0.05$ \\
After 60 minutes & $80.50 \pm 8.16$ & $80.15 \pm 9.35$ & $>0.05$ \\
\hline
\end{tabular}

\section{DISCUSSION}

Additional evidence suggested that the main site of action of clonidine is the dorsal horn of the spinal cord. ${ }^{15,16}$ Intrathecal clonidine has an analgetic effect. ${ }^{14,17,18}$ In addition, supraspinal injection of clonidine reduces the antinociceptive effect of opioid analgesic. ${ }^{19}$ The mechanism of this action of intrathecal clonidine may be an activation of the post-synaptic alpha 2-adrenoreceptors in the spinal cord. This spinal activation has been invoked to explain the efficacy in treatment of opiate withdrawal. The effect of intrathecal injection of this alpha 2-adrenoreceptor agonist on spinal cord blood flow is unknown; however local vasoconstriction in the spinal cord is not produced by epidural clonidine 3 microgram $/ \mathrm{kg} .{ }^{13}$ 
In this study, patients from group I achieved T 11 \pm 1 of analgesia level but patients of group II reached T $10 \pm 1$ after 2 minutes. Group II achieved one segment higher, though not a statistically significant.

The time to onset of total motor blockage did not differ between group ( $5.6 \pm 1.4 \mathrm{~min})$ and group II (6.7 $\pm 3.3 \mathrm{~min}$ ). Significant differences in duration of motor blockage Bromage 3,2, and 1 were found between group I and group II. Each duration of motor blockage Bromage 3,2,1 of patients in group II were extended $(180 \pm 50),(215 \pm 60),(288 \pm 60)$ min., whereas in group I it were $(105 \pm 25),(120 \pm 20),(140 \pm 25 \mathrm{~min})$. The time for regression of sensory blockage is the mean time between local analgesic and the time of regression of the level of the sensory blockage to L2. This value was significantly longer in group II (268 \pm $70 \mathrm{~min}$ ), compared with group I $(158 \pm 20 \mathrm{~min})$, ( $\mathrm{p}<$ 0.05 ). It can be assumed that addition of clonidine intrathecally is more effective in prolonging sensory blockage than prolonging motor blockage.

Bedder et al. in an animal study has shown that clonidine $0.15 \mathrm{mg}$ when used as an adjunct to tetracain spinal analgesia is as effective as epinephrine $0.2 \mathrm{mg}$ in prolonging motor blockage, but significantly more effective in prolonging sensory blockage. ${ }^{4}$ Racle et al. in their study on 60 geriatric patients for hip surgery claimed that clonidine $(0.15 \mathrm{mg})$ added to plain bupivacain $0.5 \%$ spinal analgesia is more effective than epinephrine in prolonging sensory blockage. ${ }^{20}$

Problem in studies comparing the duration of motor and especially sensory blockage following spinal anesthesia is the lack of standardization of assessment. Duration has been assessed in a number of different ways including : time to two segment or four segment regression of analgesia, time to elimination of adequate surgical analgesia, time to regression of motor blockade, or time to first use of postoperative analgetic. In this study, the method of assessment used is approximately similar to time to regression of adequate surgical analgesia.

Clonidine can prolong the sensory blockage observed with bupivacain through a spinal cord presynaptic alpha 2- adrenoreceptor mechanism, a postsynaptic alpha 2 -adrenoreceptor arteriolar effect and/or supraspinal alpha 2-antinociceptive action. Nociceptive sensory input has been shown abroad studies to be associated with central and spinal adrenergic neurons. ${ }^{18,21}$

Calvillo and Ghignone demonstrated that clonidine caused primary afferent depolarization of intraspinal cutaneous $\mathrm{C}$ fibers, thereby decreasing transmitter release through presynaptic inhibitory mechanisms. ${ }^{22}$ These studies support the role of an alpha 2-adrenoreceptor mechanism in selection of nociceptive input at the spinal level. ${ }^{4}$

Another possible mechanism of clonidine-induced prolongation of analgesia is through adrenoreceptor mediated vasoconstriction, apart from the classical alpha 1-adrenoreceptor, there is a second type of adrenergic receptor on smooth muscle cells than can mediate vasoconstriction, resembling the alpha 2 adrenoreceptor pharmacologically and these receptors may mediate vasoconstriction to exogenous catecholamines.

The direct antinociceptive effects of intrathecal alpha agonists, however, are unlikely to be secondary to local ischemia, as they have shown to be reliably reversible and unaffected in their action by vasodilator agents. ${ }^{2 s} \mathrm{~A}$ vasoactive interaction between bupivacain and clonidine much like interaction bupivacain and epinephrine, might be responsible for the prolongation of spinal anesthesia. The prolongation of sensory blockage could be explained by a synergism between the antinocciceptive effects of clonidine and the neural blocking action of bupivacain. However, since clonidine in low doses has little effect on motor function, a synergistic effect between alpha 2-adrenoreceptor function and bupivacain motor blockage seems unlikely. It is likely to explain the prolongation of motor blockage by decreased vascular uptake of bupivacain as a consequence of the alpha 2-mediated inhibition of bupivacain-induced vasodilation.

In this study, mild fall in blood pressure of both groups could be controlled easily by intravenous administration of fluid. The changes of blood pressure were assumed due to the effects of spinal anesthesia and bleeding during surgery. The effect of alpha 2adrenergic agonists on blood pressure depends on their lipophilicity and plasma concentration. Intrathecally, administration clonidine may produce hypotension by two mechanisms redistribution to brainstem sites of action and direct spinal inhibition of preganglionic sympathetic out flow. ${ }^{24}$ This action is antagonized, at certain plasma concentrations (above 1.5 and $15 \mathrm{ng} / \mathrm{ml}$ respectively), by peripheral vasoconstriction due to systemic (intrathecal) administration of clonidine. We postulate that plasma clonidine concentrations were sufficiently high following intrathecal administration to trigger peripheral vasoconstriction, thus preventing any hypotensive effect at central sites.

The prominent side effects of patients from group II were dry mouth $(30 \%)$ and sedation $(50 \%)$ that significantly differed compared with patients from group I. Clonidine can produce sedation if the plasma concentration achieves $1.5-2 \mathrm{ng} / \mathrm{ml}^{25}$ In this dose, 
clonidine would be able to inhibit secretion by salivary glands. ${ }^{25}$ Total number of these cases were not enough to support more detailed analysis.

\section{CONCLUSION}

This study concludes that spinal anaesthesia with a combination of hyperbaric bupivacain $0.5 \%(15 \mathrm{mg})$ and clonidine $(0.15 \mathrm{mg})$ extends significantly the effect of analgesia. Clonidine is effective in prolonging motor blockage, but more effective in prolonging sensory blockage. The maximum level of analgesia is not affected by clonidine. The prominent side effects of this technique are sedation and dry mouth. Further studies with more cases are required to assess dose response, haemodynamic and another side effects of clonidine.

\section{REFERENCES}

1. Adriani J. Regional anaesthesia. Philadelphia : WB Saunders Co $3^{\text {nd }}$ edition, 1969;26-379.

2. Tuominen M, Kalso E, Rosenberg PH. Effects of posture on the spread spinal anaesthesia with $0.75 \%$ and $0.5 \%$ bupivacain. Br J Anaesth 1982;54:313-8.

3. Axelsson $\mathrm{KH}$, Edstrom $\mathrm{HH}$, Widman GB, Spinal anaesthesia with glucose free $0.5 \%$ bupivacain, effect of different volume. Br J Anaesth 1984;56:271-7.

4. Bedder MD, Kozody R, Palahniuk RJ, Cumming MO, Pucci WR. Clonidine prolongs tetracain spinal anaesthesia in dogs. Anaesth Anagl 1986;65:14.

5. Gorth TE Jr, Tamsen A. A study on the analgesic effect of clonidine in man. Acta Anaesthesiol Scan 1983;27 (Suppl 87):72.

6. Bloocb. Clonidine and other alpha 2-adrenergic agonist : An important new drug class for the perioperative period. Sem in Anaesth 1988;1:231-2.

7. Melamed E, Lahav M, Atlas D. Histochemical evidence for beta- adrenergic receptors in thoracic spinal cord. Brain Res 1976;116:511-5.

8. Astrachan DI, Davis M, Gallager DW. Behavior and bindings : Correlation between alpha 1 -adrenergic stimulation of ocoustic startle and alpha 1-adrenoceprots occupancy and number in rat spinal cord. Brain Res 1983;260:81-90.

9. Probst A, Cortes R, Patacios M. Distribution of alpha 2adrenergic receptors in the human brainstem : an autoradiographic study using $(3 \mathrm{H}) \mathrm{p}$-aminoclonidine. Eur $\mathrm{J}$ Pharmacol 1984;106:477- 8.

10. Understall Jr, Kopastic TA, Kuhar MJ. Distribution of alpha 2 - agonist binding sites in the rat and human central nervous system : analysis of some functional, anatomic correlates of the pharmacologic effects of clonidine and related adrenergic agents. Brain Res Rev 1984;7:69-101.

11. Fleetwood-Walker SM, Mitchell R, Hope PJ, Molony V. An alpha 2- receptor mediates the selective inhibition by noradrinaline of nociceptive responses of identified dorsal horn neurons. Brain Res 1985;334:243-54.

12. Post C, Gordh Tyr, Minor BG, Archer T, Freedman J. Antinocicepetive effects and spinal cord tissue concentration after intrathecal injection of Guanfacine or clonidine into rats. Anesth Analg 1987;66:317-24.

13. Gordh T, Post C, Olsson Y. Evaluation of the toxicity of subarachoid clonidine, Guanfacine, and a substance P-antagonist on rat spinal cord and nerve roots. Anesth Analg 1986;65:1303- 17.

14. Bromage PR. Acomparison of the hydrochloride and carbondioxide salts of lidocain and prilocaine in epidural analgesia Acta Anaesthesiol Scand (Suppl) 1965;16:55-69.

15. Spanlding TC., Fielding S, Venatro YJ, Lac H. Antinociceptive activefy of clonidine and its potentialisation of morphine analgesia. Eur J Pharmacol 1979;58:19-25.

16. Ossipov MH, Suarez LJ, Spanlding JC. Antinociceptive interaction between alpha 2-adrenergic and opiate agonists of the spinal level in Rodents. Anesth Analg 1989;68:194200.

17. Commbs DW, Sanders RL, Lachance D, Savage S, Ragnarsson TS, Jensen LE. Intrathecal morphin tolerance : use of intrathecal clonidine, DADLE, and intraventrikular morphin. Anesthesiology 1985;62:358-63.

18. Reddy SV, Laderyt L, Yaksh TL, Spinal cord pharmacology of adrenergic agonist mediated antinociception. J.Pharmacol Exp Ther 1980;213:525-33.

19. Ossipov MH. Malodec RT, Fisenmaan LM, Goldtein FD. Effect of alpha 2-adrenergic agents upon central elorphine antinociception in rat. Brain Res 1984;309:135-42.

20. Racl JP, Bendhadra A, Poy JY, Gleizal B, Prolongation of isobaric bupivacain spinal anaesthesia with epinephrine and clonidine for hip surgery in the elderly. Anesth Analg 1987;66:442-6.

21. Reddy SYR, Yaksh TL,. Spinal noradrenergic terminal system mediating antinociception. Brain Research 1980; 189:391-401.

22. Calvillo O, Ghignone M,. Primary afferent depolarization of cutaneous $\mathrm{C}$ fibers in the cat spinal cord evoked by clonidine. Fed Proc 1985;2799:44.

23. Marwaha J, Kehne JH, Commissaris RL, Lahoshi J, Shaw W, Davis M., Spinal clonidine inhibits neural firing in locus coerulens. Brain Research 1983;276:379-82.

24. Eisenach J, Deinan DM, Rose JG, Angelo JM. Epidural clonidine prouces antinociception but not hypotension in sheep. Anesthesiology 1987;66:490-501.

25. Houston MC. Clonidine hydrochloride. South Med J 1982;75:713-21. 